\title{
Impact of Zinc Application on Leaf Growth Parameters of Mungbean (Vigna radiata L.) under Water Stress
}

\author{
B. Srikanth ${ }^{1 *}$, K. Jayalalitha ${ }^{1}$ and M. Sree Rekha ${ }^{2}$ \\ ${ }^{1}$ Department of Crop Physiology, ${ }^{2}$ Department of Agronomy, Agricultural College, \\ Bapatla, ANGRAU, Andhra Pradesh, India \\ *Corresponding author
}

\section{A B S T R A C T}

\begin{tabular}{|l|}
\hline Ke y w o r d s \\
$\begin{array}{l}\text { Water stress, Leaf } \\
\text { area, Foliar spray, } \\
\text { Zinc and Mungbean }\end{array}$ \\
\hline Article Info \\
\hline $\begin{array}{l}\text { Accepted: } \\
\text { 16 November } 2020 \\
\text { Available Online: } \\
\text { 10 December } 2020\end{array}$ \\
\hline
\end{tabular}

A field experiment was conducted during rabi season of 2017-18 at Agricultural College Farm, Bapatla to study the impact of seed pre - treatment and foliar application of zinc on leaf growth parameters of mungbean under water stress. The experiment was laid out in split plot design with three replications consists of two main treatments viz., no stress i.e. control (M0) and stress from flowering stage (i.e. from 30 DAS) up to harvest (M1) and seven sub-treatments viz., no zinc application (S0), seed treatment with $0.05 \%$ and $0.075 \%$ ZnSO4 solutions for $5 \mathrm{hrs}$ before sowing (S1 and S2), foliar spray of 300, 400 and 500 ppm ZnSO4 at 30 DAS (S3, S4 and S5) and water spray at 30 DAS (S6). The results showed that leaf area was reduced by 14.8 per cent in the plants that were subjected to stress from flowering stage over control plants. Foliar zinc spray @ 500 ppm at 30 DAS increased the leaf area by 30.0 per cent, over untreated plants at 45 DAS. Normal irrigated plants sprayed with zinc @ 500 ppm $\left(\mathrm{M}_{0} \mathrm{~S}_{5}\right)$ recorded the highest values of leaf area and the lowest values were recorded by the stressed plants with no zinc application $\left(M_{1} S_{0}\right)$. Under water stress, mungbean plants sprayed with zinc @ 500 ppm at 30 DAS $\left(M_{1} S_{5}\right)$ increased the leaf area by 23.9 per cent, over unsprayed plants $\left(M_{1} S_{0}\right)$.

\section{Introduction}

Mungbean is an excellent source of high quality protein in vegetarian diet of Indian population and is particularly preferred for invalids and infants for its easy digestability and non flatulance protein. It is cultivated in India since ancient times. The productivity of mungbean is very low, because it is grown in marginal and sub marginal lands with low fertilizer under rainfed conditions. It is frequently grown where soil moisture is a limiting factor for successful crop production. It is cultivated throughout India and occupies an area of about 3.09 million hectares with a production of 1.54 million tonnes and productivity of $499 \mathrm{~kg} \mathrm{ha}^{-1}$.

In Andhra Pradesh, it is grown in an area of about 0.27 million hectares, with a production of 0.18 million tonnes and with an average productivity of $651 \mathrm{~kg} \mathrm{ha}^{-1}$ (Ministry of Agriculture, 2016-17). 
Zinc is an essential micronutrient which is involved in many physiological functions such as auxin biosynthesis, activation of dehydrogenase enzymes and stabilization of ribosomal fractions (Aghatise and Tayo, 1994), protein and carbohydrate synthesis (Yadavi et al., 2014). It is essential for the biosynthesis of the carbonic anhydrase enzyme required for chlorophyll biosynthesis (Xi-Wen et al., 2011), and also as a key constituent of alcohol dehydrogenase and superoxide dismutase (Welch et al., 1982).

Zinc application in maize improves photosynthetic rate, chlorophyll synthesis, nitrogen metabolism and resistance to both biotic and abiotic stresses (Ali et al., 2008). The application of zinc under drought conditions would influence crop yield and quality. It plays a significant role in regulating stomatal opening and closing and ionic balance in crops and reduces the detrimental effects of drought (Moghadam et al., 2013) and also has protective effects on oxidative damage caused by ROS in response to stresses (Akbari et al., 2013). Therefore, the present investigation was undertaken to study the impact of seed pre-treatment and foliar application of zinc on leaf growth parameters of mungbean plants.

\section{Materials and Methods}

The experiment was conducted during Rabi, 2017-18 at Agricultural college farm, Bapatla. The experiment was laid out in a Split Plot Design, replicated thrice with a plot size of 12 square meter and the row spacing of $30 \mathrm{~cm}$ and intra row spacing of $10 \mathrm{~cm}$.

Sowing was done by dibbling and recommended dose of fertilizers were applied and other package of practices were followed to raise a healthy crop. Prophylactic measures were adopted against pests and diseases.

\section{Leaf area}

Leaves from the five adjacent plants sampled from each treatment in three replications were separated and leaf area was measured by using Leaf Area Meter (Model No. LP-80) and the average was expressed as leaf area plant ${ }^{-1}$ in $\mathrm{cm}^{2}$.

\section{Specific leaf weight (SLW)}

The specific leaf weight was determined by using the formula of Pearce et al., (1968) and expressed in $\mathrm{mg} \mathrm{cm}^{-2}$.

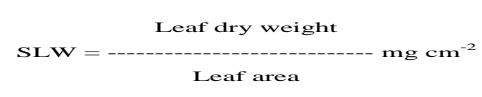

\section{Specific leaf area (SLA)}

The specific leaf area was determined by using the formula of Kvet et al., (1971) and expressed in $\mathrm{cm}^{2} \mathrm{~g}^{-1}$.

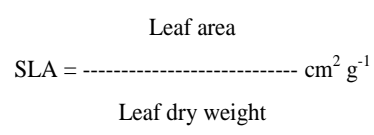

\section{Results and Discussion}

\section{Leaf area $\left(\mathrm{cm}^{2}\right.$ plant $\left.^{-1}\right)$}

The data pertaining to leaf area per plant as affected by water stress and zinc treatments were recorded at 15 days interval from 15 to 60 DAS and were presented in Table 1. Production and maintenance of leaf area is important for dry matter production and yield. The leaf area per plant showed a gradual increase upto 45 DAS and then declined at 60 DAS. Among the main treatments, significant differences were observed at 45 and 60 DAS only. At 45 and 60 DAS, the plants that were stressed from flowering stage recorded lesser leaf area per plant $\left(\mathrm{M}_{1}-365.40\right.$ and 314.30 $\mathrm{cm}^{2}$, respectively) compared to control i.e. no stress $\left(\mathrm{M}_{0}-428.98\right.$ and $369.07 \mathrm{~cm}^{2}$, 
respectively). In the current study, leaf area per plant was decreased by 14.8 per cent in the treatment where the plants were subjected to water stress from flowering stage compared to control i.e. no stress, both at 45 and 60 DAS. These results coincide with those obtained by Thalooth et al., (2006), who reported that skipping one irrigation at vegetative, flowering and pod formation stages significantly reduced the leaf area in mungbean plants compared to control (i.e. unstressed) plants.

The depressing effect of drought on plant growth was to be attributed to the decreased synthesis of metabolites, reduced translocation of nutrients from the soil to the plant as well as decreased cell division and elongation of cells. Moreover, water stress caused a progressive decline in net photosynthetic rate which is associated with simultaneous decrease in leaf area and starch content (Thalooth et al., 2006).

Among the sub treatments, significant differences were noted at 15, 30, 45 and 60 DAS. At 15 and 30 DAS, seed pre - treatment with zinc @ $0.075 \%$ before sowing recorded higher leaf area per plant $\left(S_{2}-45.65\right.$ and $285.37 \mathrm{~cm}^{2}$, respectively) compared to control and other zinc treatments. Except the treatment $\mathrm{S}_{1}$ (i.e. seed pre - treatment with zinc@0.05\%), remaining treatments were at par with each other.

The treatment $S_{1}$ recorded significantly lesser leaf area (42.00 and $250.43 \mathrm{~cm}^{2}$ ) than $S_{2}$ and higher leaf area than other treatments at 15 and 30 DAS, respectively. At 45 and 60 DAS, foliar application of zinc @ 500 ppm at 30 DAS recorded the highest leaf area per plant $\left(\mathrm{S}_{5}-436.88\right.$ and $375.86 \mathrm{~cm}^{2}$, respectively) followed by seed pre - treatment with zinc @ $0.075 \%$ before sowing $\left(S_{2}-418.17\right.$ and $359.76 \mathrm{~cm}^{2}$, respectively), whereas the lowest leaf area was recorded in control plants i.e. no zinc application $\left(\mathrm{S}_{0}-361.20\right.$ and $310.75 \mathrm{~cm}^{2}$, respectively). The remaining treatments were inferior to $S_{5}$ and $S_{2}$, and superior over control (i.e. no zinc application). At 45 and 60 DAS, foliar application of zinc @ 500 ppm at 30 DAS recorded 30.0 and 21.0 per cent increase in leaf area, respectively, over the plants that were not treated with zinc $\left(\mathrm{S}_{0}\right)$.

Seed pre - treatment with zinc @ 0.075\% before sowing recorded 15.8 per cent increase in leaf area per plant over untreated plants (i.e. control) both at 45 and 60 DAS. Quddus et al., (2011) stated that, zinc application @ $1.5 \mathrm{~kg} \mathrm{ha}^{-1}$ increased the plant height, number of branches, functional leaves and leaf area in mungbean. In the present study, increased leaf area with foliar spray of zinc @ 500 ppm might be due to increased plant height and more number of branches.

Among the interactions, significant difference was observed from 45 DAS upto maturity (60DAS). At $45 \mathrm{DAS}$, the highest leaf area was recorded with unstressed plants (irrigated plants) sprayed with zinc @ 500 ppm $\left(\mathrm{M}_{0} \mathrm{~S}_{5}-\right.$ $462.94 \mathrm{~cm}^{2}$ ) and the lowest leaf area was obtained with the plants that were stressed from flowering stage with no zinc application $\left(\mathrm{M}_{1} \mathrm{~S}_{0}-331.63 \mathrm{~cm}^{2}\right)$. Foliar application of zinc@ @ 500 ppm to the plants that were stressed from flowering stage recorded higher leaf area $\left(\mathrm{M}_{1} \mathrm{~S}_{5}-410.82 \mathrm{~cm}^{2}\right)$ over $\mathrm{M}_{1} \mathrm{~S}_{0}$ $\left(331.63 \mathrm{~cm}^{2}\right)$ and $\mathrm{M}_{0} \mathrm{~S}_{0}$ (i.e. irrigated plants with no zinc application - $390.77 \mathrm{~cm}^{2}$ ) treatments. Similar trend was observed at 60 DAS also. The efficacy of different zinc treatments on improvement of leaf area of mungbean under water stress condition in the present study is in the order of $\mathrm{S}_{5}, \mathrm{~S}_{2}, \mathrm{~S}_{4}, \mathrm{~S}_{1}$ and $S_{3}$. Karim et al., (2012) reported that foliar application of zinc @ $0.05 \%$ significantly increased the values for SPAD and leaf area in winter wheat under rainfed conditions (Fig. 1). 
Table.1 Effect of zinc on leaf area $\left(\mathrm{cm}^{2}\right.$ plant $\left.{ }^{-1}\right)$ of mungbean under water stress

\begin{tabular}{|c|c|c|c|c|c|c|c|c|c|c|c|c|}
\hline \multirow[t]{2}{*}{ Treatments } & \multicolumn{3}{|c|}{15 DAS } & \multicolumn{3}{|c|}{30 DAS } & \multicolumn{3}{|c|}{45 DAS } & \multicolumn{3}{|c|}{60 DAS } \\
\hline & $\mathbf{M}_{0}$ & $\mathbf{M}_{1}$ & Mean & $\mathbf{M}_{0}$ & $\mathbf{M}_{1}$ & Mean & $\mathbf{M}_{0}$ & $\mathbf{M}_{1}$ & Mean & $\mathbf{M}_{0}$ & $\mathbf{M}_{1}$ & Mean \\
\hline$S_{0}:$ No Zinc application & 38.00 & 37.23 & 37.62 & 181.57 & 170.23 & 175.90 & 390.77 & 331.63 & 361.20 & 336.19 & 285.31 & 310.75 \\
\hline $\begin{array}{l}S_{1}: \text { Seed treatment with Zinc } \\
@ 0.05 \% \text { before sowing }\end{array}$ & 42.50 & 41.50 & 42.00 & 256.03 & 244.83 & 250.43 & 429.36 & 360.20 & 394.78 & 369.39 & 309.89 & 339.64 \\
\hline $\begin{array}{l}S_{2}: \text { Seed treatment with Zinc } \\
@ 0.075 \% \text { before sowing }\end{array}$ & 46.70 & 44.60 & 45.65 & 289.57 & 281.17 & 285.37 & 448.57 & 387.76 & 418.17 & 385.92 & 333.61 & 359.76 \\
\hline $\begin{array}{l}S_{3}: \text { Foliar spray of Zinc @ } 300 \\
\text { ppm at } 30 \text { DAS }\end{array}$ & 37.17 & 38.47 & 37.82 & 171.30 & 190.50 & 180.90 & 417.00 & 349.67 & 383.33 & 358.76 & 300.83 & 329.80 \\
\hline $\begin{array}{l}S_{4}: \text { Foliar spray of Zinc @ } 400 \\
\text { ppm at } 30 \text { DAS }\end{array}$ & 37.93 & 36.67 & 37.30 & 178.77 & 190.73 & 184.75 & 441.22 & 376.23 & 408.73 & 379.60 & 323.69 & 351.64 \\
\hline $\begin{array}{l}S_{5}: \text { Foliar spray of Zinc @ } 500 \\
\text { ppm at } 30 \text { DAS }\end{array}$ & 37.47 & 37.93 & 37.70 & 179.00 & 172.40 & 175.70 & 462.94 & 410.82 & 436.88 & 398.29 & 353.44 & 375.86 \\
\hline $\begin{array}{l}S_{6}: \text { Foliar spray of water at } 30 \\
\text { DAS }\end{array}$ & 36.70 & 39.00 & 37.85 & 178.33 & 178.73 & 178.53 & 412.99 & 341.49 & 377.24 & 355.31 & 293.33 & 324.32 \\
\hline \multirow[t]{2}{*}{ Mean } & 39.50 & 39.34 & & 204.94 & 204.56 & & 428.98 & 365.40 & & 369.07 & 314.30 & \\
\hline & SEm \pm & CD & $\begin{array}{l}\text { CV } \\
(\%)\end{array}$ & SEm \pm & CD & $\begin{array}{l}\text { CV } \\
(\%)\end{array}$ & SEm \pm & CD & $\begin{array}{l}\text { CV } \\
(\%)\end{array}$ & SEm \pm & CD & $\begin{array}{l}\text { CV } \\
(\%)\end{array}$ \\
\hline Main & 0.32 & NS & 6.77 & 2.91 & NS & 6.55 & 0.96 & 5.82 & 8.32 & 0.81 & 4.96 & 8.54 \\
\hline Sub & 0.64 & 1.88 & 7.01 & 3.96 & 11.26 & 7.76 & 1.89 & 5.53 & 7.41 & 1.65 & 4.82 & 7.89 \\
\hline Interactions & 0.91 & NS & & 5.60 & NS & & 2.68 & 7.81 & & 2.34 & 6.82 & \\
\hline
\end{tabular}


Table.2 Effect of zinc on specific leaf weight $\left(\mathrm{mg} \mathrm{cm}^{-2}\right)$ of mungbean under water stress

\begin{tabular}{|c|c|c|c|c|c|c|c|c|c|c|c|c|}
\hline \multirow[t]{2}{*}{ Treatments } & \multicolumn{3}{|c|}{15 DAS } & \multicolumn{3}{|c|}{30 DAS } & \multicolumn{3}{|c|}{45 DAS } & \multicolumn{3}{|c|}{60 DAS } \\
\hline & $\mathbf{M}_{\mathbf{0}}$ & $\mathbf{M}_{1}$ & $\begin{array}{c}\text { Mea } \\
\mathbf{n}\end{array}$ & $\mathbf{M}_{\mathbf{0}}$ & $\mathbf{M}_{1}$ & $\begin{array}{c}\text { Mea } \\
\mathbf{n}\end{array}$ & $\mathbf{M}_{\mathbf{0}}$ & $\mathbf{M}_{1}$ & $\begin{array}{c}\text { Mea } \\
\mathbf{n}\end{array}$ & $\mathbf{M}_{\mathbf{0}}$ & $\mathbf{M}_{1}$ & $\underset{\mathbf{n}}{\mathrm{Mea}}$ \\
\hline S0 : No Zinc application & 3.40 & 3.57 & 3.49 & 6.16 & 5.93 & 6.05 & 9.93 & 10.31 & 10.12 & 10.15 & 10.95 & 10.75 \\
\hline $\begin{array}{l}\text { S1 : Seed treatment with Zinc @ } \\
0.05 \% \text { before sowing }\end{array}$ & 3.47 & 3.57 & 3.52 & 5.62 & 5.76 & 5.69 & 9.87 & 10.57 & 10.22 & 10.48 & 11.23 & 10.85 \\
\hline $\begin{array}{l}\text { S2 : Seed treatment with Zinc @ } \\
0.075 \% \text { before sowing }\end{array}$ & 3.39 & 3.63 & 3.51 & 5.74 & 5.91 & 5.82 & 9.52 & 10.84 & 10.18 & 10.11 & 11.51 & 10.81 \\
\hline $\begin{array}{l}\text { S3 : Foliar spray of Zinc @ } 300 \\
\text { ppm at } 30 \text { DAS }\end{array}$ & 3.34 & 3.58 & 3.46 & 6.42 & 5.15 & 5.78 & 10.08 & 10.96 & 10.52 & 10.70 & 11.64 & 11.17 \\
\hline $\begin{array}{l}\text { S4 : Foliar spray of Zinc @ } 400 \\
\text { ppm at } 30 \text { DAS }\end{array}$ & 3.43 & 3.75 & 3.59 & 6.34 & 4.94 & 5.64 & 9.75 & 11.40 & 10.58 & 10.35 & 12.11 & 11.23 \\
\hline $\begin{array}{l}\text { S5 : Foliar spray of Zinc @ } 500 \\
\text { ppm at } 30 \text { DAS }\end{array}$ & 3.58 & 3.64 & 3.61 & 6.13 & 6.08 & 6.11 & 9.37 & 11.42 & 10.39 & 9.94 & 12.12 & 11.03 \\
\hline $\begin{array}{l}\text { S6 : Foliar spray of water at } 30 \\
\text { DAS }\end{array}$ & 3.71 & 3.56 & 3.64 & 6.19 & 5.80 & 6.00 & 9.88 & 10.04 & 9.96 & 10.48 & 10.66 & 10.57 \\
\hline \multirow[t]{2}{*}{ Mean } & 3.47 & 3.62 & & 6.08 & 5.65 & & 9.77 & 10.79 & & 10.37 & 11.46 & \\
\hline & $\begin{array}{l}\text { SEm } \\
\pm\end{array}$ & CD & $\begin{array}{l}\text { CV } \\
(\%)\end{array}$ & $\begin{array}{c}\text { SEm } \\
\pm\end{array}$ & CD & $\begin{array}{l}\text { CV } \\
(\%)\end{array}$ & $\begin{array}{l}\text { SEm } \\
\pm\end{array}$ & CD & $\begin{array}{l}\text { CV } \\
(\%)\end{array}$ & $\begin{array}{l}\text { SEm } \\
\pm\end{array}$ & CD & $\begin{array}{l}\text { CV } \\
(\%)\end{array}$ \\
\hline Main & 0.02 & NS & 4.56 & 0.16 & NS & 12.75 & 0.02 & 0.14 & 5.68 & 0.02 & 0.15 & 7.48 \\
\hline Sub & 0.09 & NS & 6.57 & 0.18 & 0.50 & 7.66 & 0.06 & 0.17 & 6.35 & 0.06 & 0.18 & 6.87 \\
\hline Interactions & 0.12 & NS & & 0.25 & NS & & 0.08 & 0.25 & & 0.09 & 0.26 & \\
\hline
\end{tabular}


Table.3 Effect of zinc on specific leaf area $\left(\mathrm{cm}^{2} \mathrm{~g}^{-1}\right)$ of mungbean under water stress

\begin{tabular}{|c|c|c|c|c|c|c|c|c|c|c|c|c|}
\hline \multirow[t]{2}{*}{ Treatments } & \multicolumn{3}{|c|}{15 DAS } & \multicolumn{3}{|c|}{30 DAS } & \multicolumn{3}{|c|}{45 DAS } & \multicolumn{3}{|c|}{60 DAS } \\
\hline & $\mathbf{M}_{0}$ & $\mathbf{M}_{1}$ & Mean & $\mathbf{M}_{0}$ & $\mathbf{M}_{1}$ & Mean & $\mathbf{M}_{0}$ & $\mathbf{M}_{1}$ & Mean & $\mathbf{M}_{0}$ & $\mathbf{M}_{1}$ & Mean \\
\hline$S_{0}:$ No Zinc application & 294.1 & 280.1 & 287.1 & 162.3 & 168.8 & 165.5 & 97.0 & 100.8 & 98.9 & 108.3 & 75.5 & 91.9 \\
\hline $\begin{array}{l}S_{1}: \text { Seed treatment with Zinc } \\
\text { @ } 0.05 \% \text { before sowing }\end{array}$ & 289.2 & 280.6 & 284.9 & 203.6 & 197.6 & 200.6 & 94.7 & 101.3 & 98.0 & 113.8 & 74.8 & 94.3 \\
\hline $\begin{array}{l}S_{2}: \text { Seed treatment with Zinc } \\
\text { @ } 0.075 \% \text { before sowing }\end{array}$ & 295.1 & 275.4 & 285.2 & 211.2 & 204.0 & 207.6 & 92.3 & 105.0 & 98.7 & 114.5 & 75.2 & 94.8 \\
\hline $\begin{array}{l}S_{3}: \text { Foliar spray of Zinc @ } \\
300 \text { ppm at } 30 \text { DAS }\end{array}$ & 299.9 & 279.5 & 289.7 & 155.8 & 194.6 & 175.2 & 94.3 & 103.6 & 98.9 & 114.3 & 73.2 & 93.7 \\
\hline $\begin{array}{l}S_{4}: \text { Foliar spray of Zinc @ } \\
400 \text { ppm at } 30 \text { DAS }\end{array}$ & 296.1 & 267.0 & 281.6 & 158.8 & 203.1 & 181.0 & 87.8 & 102.7 & 95.2 & 113.4 & 70.5 & 92.0 \\
\hline $\begin{array}{l}S_{5}: \text { Foliar spray of Zinc @ } \\
500 \text { ppm at } 30 \text { DAS }\end{array}$ & 279.9 & 274.8 & 277.3 & 164.5 & 165.5 & 165.0 & 87.7 & 106.8 & 97.3 & 113.4 & 73.3 & 93.3 \\
\hline $\begin{array}{l}S_{6}: \text { Foliar spray of water at } 30 \\
\text { DAS }\end{array}$ & 270.9 & 280.7 & 275.8 & 164.2 & 173.0 & 168.6 & 99.8 & 100.6 & 100.2 & 118.3 & 79.8 & 99.0 \\
\hline \multirow[t]{2}{*}{ Mean } & 289.3 & 276.9 & & 174.3 & 186.6 & & 93.4 & 103.0 & & 113.7 & 74.6 & \\
\hline & $\begin{array}{l}\text { SEm } \\
\pm\end{array}$ & CD & $\begin{array}{l}\text { CV } \\
(\%)\end{array}$ & $\begin{array}{c}\text { SEm } \\
\pm\end{array}$ & CD & $\begin{array}{l}\text { CV } \\
(\%)\end{array}$ & $\begin{array}{c}\text { SEm } \\
\pm\end{array}$ & CD & $\begin{array}{l}\text { CV } \\
(\%)\end{array}$ & $\begin{array}{c}\text { SEm } \\
\pm\end{array}$ & CD & $\begin{array}{l}\text { CV } \\
(\%)\end{array}$ \\
\hline Main & 1.43 & 8.69 & 2.31 & 5.18 & NS & 13.14 & 0.07 & 0.44 & 0.34 & 0.65 & 3.97 & 3.17 \\
\hline Sub & 7.16 & NS & 6.20 & 4.97 & 14.52 & 6.75 & 1.27 & NS & 3.16 & 0.74 & 2.16 & 1.93 \\
\hline Interactions & 10.13 & NS & & 7.03 & 20.53 & & 1.79 & 5.23 & & 1.05 & 3.05 & \\
\hline
\end{tabular}


Fig.1 Effect of zinc on leaf area $\left(\mathrm{cm}^{2}\right.$ plant $\left.{ }^{-1}\right)$ of mungbean under water stress

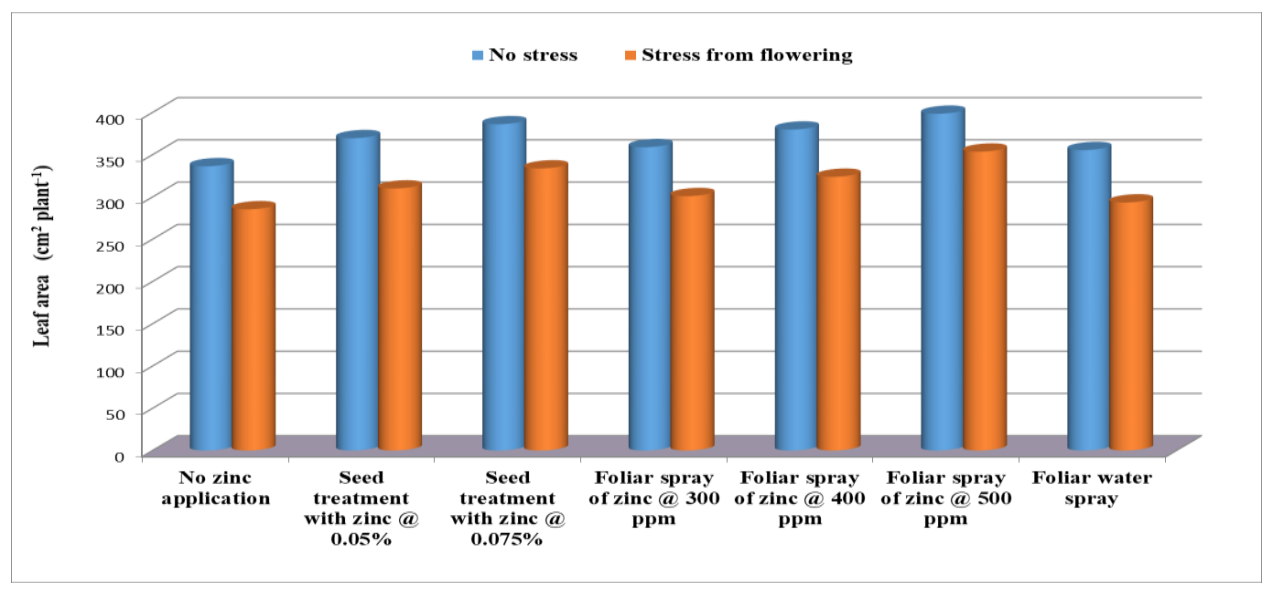

Fig.2 Effect of zinc on specific leaf weight $\left(\mathrm{mg} \mathrm{cm}^{-2}\right)$ of mungbean under water stress

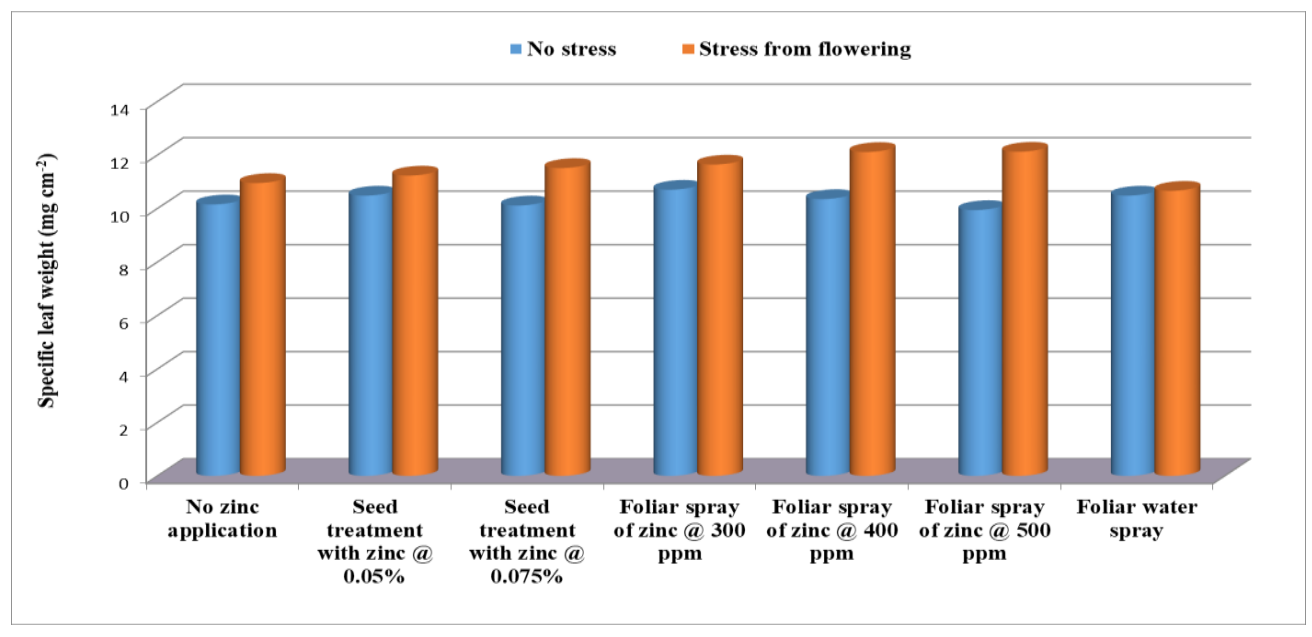

Fig.3 Effect of zinc on specific leaf area $\left(\mathrm{cm}^{2} \mathrm{~g}^{-1}\right)$ of mungbean under water stress

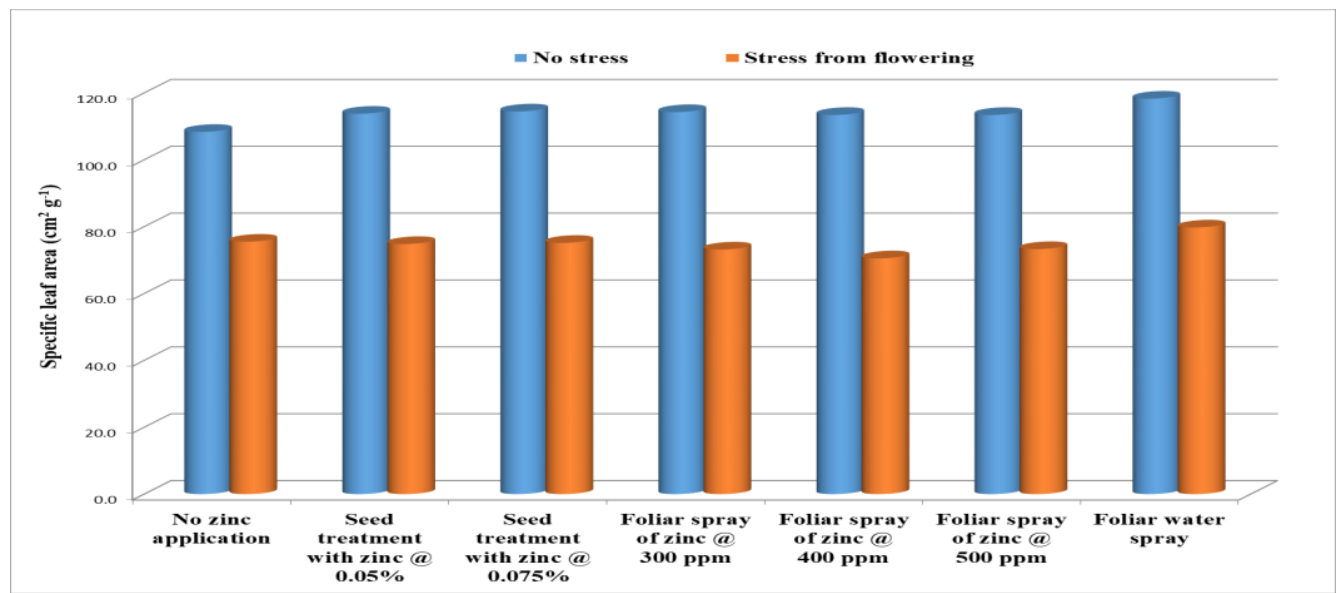




\section{Specific Leaf Weight (SLW)}

The data pertaining to the influence of water stress and zinc treatments on specific leaf weight of mungbean were presented in Table 2. Significant difference was observed among the main treatments after imposition of water stress from flowering stage. At 45 and 60 DAS, the plants that were subjected to water stress from flowering stage recorded higher SLW $\left(\mathrm{M}_{1}-10.79\right.$ and $11.46 \mathrm{mg} \mathrm{cm} \mathrm{cm}^{-2}$, respectively) compared to irrigated plants $\left(\mathrm{M}_{0}\right.$ - 9.77 and $10.37 \mathrm{mg} \mathrm{cm}^{-2}$, respectively). Water stress treatment increased the SLW by 10.4 and 10.5 per cent over control (i.e. no stress) at 45 and 60 DAS, respectively.

Among the sub treatments, significant differences were observed from 45 to 60 DAS. At 45 and 60 DAS, foliar spray of zinc @ $400 \mathrm{ppm}$ at $30 \mathrm{DAS}$ recorded the highest SLW $\left(\mathrm{S}_{4}-10.58\right.$ and $11.23 \mathrm{mg} \mathrm{cm}{ }^{-2}$, respectively), which was statistically at par with the spray of zinc @ $300 \mathrm{ppm}\left(\mathrm{S}_{3}-10.52\right.$ and $11.17 \mathrm{mg} \mathrm{cm}^{-2}$, respectively). The lowest SLW was recorded by foliar spray of water at 30 DAS $\left(\mathrm{S}_{6}-9.96\right.$ and $10.57 \mathrm{mg} \mathrm{cm}{ }^{-2}$, respectively). Seed pre - treatment with zinc @ 0.05 and $0.075 \%$ before sowing $\left(S_{1}\right.$ and $\left.S_{2}\right)$ recorded higher SLW values compared to untreated plants and lesser SLW values compared to other zinc foliar sprays. Foliar spray of zinc @ 400 and 300 ppm increased the SLW by 4.5 and 3.9 per cent, respectively, over control plants (i.e. no zinc application) and 6.2 and 5.7 per cent, respectively, over foliar spray of water $\left(\mathrm{S}_{6}\right)$ (Fig. 2).

Significant differences were observed among the interactions at 45 and 60 DAS. At 60 DAS, highest SLW was recorded by the foliar application of zinc @ 500 ppm at 30 DAS to the plants that were stressed from flowering stage $\left(\mathrm{M}_{1} \mathrm{~S}_{5}-12.12 \mathrm{mg} \mathrm{cm}^{-2}\right)$ and the lowest SLW was recorded with foliar spray of water to the plants that were stressed from flowering stage $\left(\mathrm{M}_{1} \mathrm{~S}_{6}-10.66 \mathrm{mg} \mathrm{cm}^{-2}\right)$. In the present study, higher SLW values were recorded in the plants that were stressed from flowering stage with zinc treatments compared to the irrigated plants with zinc application.

\section{Specific Leaf Area (SLA)}

The data pertaining to the influence of water stress and zinc treatments on specific leaf area of mungbean were presented in Table 3 . Significant difference was observed among the main treatments after imposition of water stress from flowering stage. At $60 \mathrm{DAS}$, the plants that were subjected to water stress from flowering stage recorded lower SLA ( $\mathrm{M}_{1}-74.6$ $\left.\mathrm{cm}^{2} \mathrm{~g}^{-1}\right)$ compared to irrigated plants $\left(\mathrm{M}_{0}-\right.$ $113.7 \quad \mathrm{~cm}^{2} \mathrm{~g}^{-1}$ ). Water stress treatment decreased the SLA by 34.3 per cent over control (i.e. no stress) at 60 DAS. The lower values of SLA under water stress condition is attributed due to decrease in leaf area and increase in leaf thickness under moisture stress condition, which is an adaptive mechanism to reduce transpiration.

Among the sub treatments, significant differences were observed at 30 and 60 DAS. At 30 DAS, seed pre - treatment with zinc @ $0.075 \%$ before sowing $\left(S_{2}-207.6 \mathrm{~cm}^{2} \mathrm{~g}^{-1}\right)$ recorded higher SLA whereas lowest values were noticed with foliar application of zinc @ $500 \mathrm{ppm}$ at 30 DAS $\left(\mathrm{S}_{5}-165.0 \mathrm{~cm}^{2} \mathrm{~g}^{-1}\right)$. At 60 DAS, foliar water spray $\left(\mathrm{S}_{6}-99.0 \mathrm{~cm}^{2} \mathrm{~g}^{-1}\right)$ recorded higher SLA whereas lowest values were observed with no zinc application $\left(\mathrm{S}_{0}-\right.$ $91.9 \mathrm{~cm}^{2} \mathrm{~g}^{-1}$ ). Significant differences were observed among the interactions at 30, 45 and 60 DAS. At 60 DAS, highest SLA was recorded by the foliar spray of water to the irrigated plants $\left(\mathrm{M}_{0} \mathrm{~S}_{6}-118.3 \mathrm{~cm}^{2} \mathrm{~g}^{-1}\right)$ and the lowest SLA was recorded with foliar spray of zinc @ 400 ppm at 30 DAS to the plants that were stressed from flowering stage $\left(\mathrm{M}_{1} \mathrm{~S}_{4}-\right.$ $70.5 \mathrm{~cm}^{2} \mathrm{~g}^{-1}$ ). In the present study, lower SLA values were recorded in the plants that were 
stressed from flowering stage with zinc treatments compared to the irrigated plants with zinc application (Fig. 3).

In conclusion the current study revealed that seed pretreatment and foliar application of zinc on mungbean plants have counteracted the negative effects of water stress on leaf growth. Foliar spray of zinc @ 500 ppm at 30 DAS have shown better results compared to other treatments in mitigating the deleterious effects of water stress on mungbean from flowering stage.

\section{References}

Aghatise, V.O and Tayo, T.O. 1994. Response of mungbean to zinc application in Nigeria. Indian Journal of Agricultural Sciences. 64 (9): 597-603.

Akbari, G.A., Amirinejad, M., Bagizadeh, A., Allahdadi, I and Shahbazi, M. 2013. Effect of $\mathrm{Zn}$ and Fe foliar application on yield, yield components and some physiological traits of cumin (Cuminum cyminum) in dry farming. International Journal of Agronomy and Plant Production. 4(12): 3231-3237.

Ali, S., Riaz, K.A., Mairaz, G., Arif, M., Fida, $\mathrm{M}$ and Bibi, S. 2008. Assessment of different crop nutrient management practices for yield improvement. Australian Journal of Crop Sciences. 2: 150-157.

Karim, Md. R., Zhang, Y. Q., Zhao, R.R., Chen, X.P., Zhang, F.S and Zou C.Q. 2012. Alleviation of drought stress in winter wheat by late foliar application of zinc, boron and manganese. Journal of Plant Nutrition and Soil Science. 175: 142-151.

Kvet, J., Ondok, J. Necas and R.G. Jarvis. 1971. Method of growth analysis. In Sestak, Z.J. Catsky and P.G.Jarvis (eds.). Plant photosynthetic production manual of methods, Dr. W. Junk
Publishers, Hague. 343-391.

Ministry of Agriculture, Government of India, http://www.Indiaagristat.com.

Moghadam, H.R.T., Zahedi, H and Ashkiani, A. 2013. Effect of zinc foliar application on auxin and gibberellin hormones and catalase and superoxide dismutase enzyme activity of corn (Zea mays L.) under water stress. Maydica Electronic Publication. 58: 218-223.

Pearce, R.B., Brown, R.H and Blaser, R.E. 1968. Photosynthesis of alfalfa leaves as influenced by age and environment. Crop Science. 8: 677-680.

Quddus, M.A., Rashid, M.H., Hossain, M.A and Naser, H.M. 2011. Effect of zinc and boron on yield and yield contributing characters of mungbean in low Ganges river floodplain soil at Madaripur, Bangladesh. Bangladesh Journal of Agricultural Research. 36 (1): 75-85.

Thalooth, A.T., Tawfik, M.M and Mohamed, H.M. 2006. A comparative study on the effect of foliar application of zinc, potassium and magnesium on growth, yield and some chemical constituents of mungbean plants grown under water stress conditions. World Journal of Agricultural Sciences. 2 (1): 37-46.

Welch, R.W., Webb, M.J and Loneragan, J.F. 1982. Zinc in membrane function and its role in phosphorus toxicity. Plant Nutrition, proceeding of the $9^{\text {th }}$ International Plant Nutrition Colloquium, Warwick University, U.K., PP. 710-715.

Xi-Wen, Y., Xiao-Hong, L., Xin-Chun, T., William, G.J and Yu-Xian, C. 2011. Foliar zinc fertilization improves the zinc nutritional value of wheat (Triticum aestivum L.) grain. African Journal of Biotechnology. 10: 14778-14785.

Yadavi, A., Aboueshaghi, R.S., Dehnavi, M.M and Balouchi, H. 2014. Effect of micronutrients foliar application on 
grain qualitative characteristics and some physiological traits of bean (Phaseolus vulgaris L.) under drought stress. Indian Journal of Fundamental and Applied Life Sciences. 4 (4): 124131.

\section{How to cite this article:}

Srikanth, B., K. Jayalalitha and Sree Rekha, M. 2020. Impact of Zinc Application on Leaf Growth Parameters of Mungbean (Vigna radiata L.) under Water Stress. Int.J.Curr.Microbiol.App.Sci. 9(12): 2481-2490. doi: https://doi.org/10.20546/ijcmas.2020.912.293 